九州大学学術情報リポジトリ

Kyushu University Institutional Repository

\title{
Phylogenetic Relationships among Tea Cultivars Based on AFLP Analysis
}

Lee, Seonha

Department of Agricultural Education, College of Education, Sunchon National University

Kim, Jungho

Department of Agricultural Chemistry, Sunchon National University

Sano, Junichi

Faculty of Education and Culture, Miyazaki University

Ozaki, Yukio

Laboratory of Horticultural Science, Division of Agricultural Botany, Department of Plant Resources, Faculty of Agriculture, Kyushu University

他

https://doi.org/10.5109/4498

出版情報：九州大学大学院農学研究院紀要. 47 (2)，pp. 289-299，2003-02-01. Faculty of Agriculture, Kyushu University

バージョン :

権利関係 : 


\title{
Phylogenetic Relationships among Tea Cultivars Based on AFLP Analysis
}

\author{
Seonha LEE ${ }^{1 \dagger}$, Jungho KIM², Junichi SANO ${ }^{3}$, Yukio OZAKI ${ }^{4 *}$ \\ and Hiroshi OKUBO
}

\author{
'Department of Agricultural Education, College of Education, Sunchon National University, \\ Sunchon 315, Korea ${ }^{2}$ Department of Agricultural Chemistry, Sunchon National \\ University, Sunchon 315 , Korea ${ }^{3}$ Faculty of Education and Culture, Miyazaki \\ University, Miyazaki 889-2192, Japan ${ }^{4}$ Laboratory of Horticultural Science, \\ Division of Agricultural Botany, Department of Plant Resources, Faculty \\ of Agriculture, Kyushu University, Fukuoka 812-8581, Japan \\ (Received October 29, 2002 and accepted November 7, 2002)
}

\begin{abstract}
Several modifications of the AFLP protocol were made to simplify the analysis, i.e., the amount of the reagents for restriction digestion, ligation of adaptors, preamplification and selective amplification, the primers without labeling, and the gel staining with ethidium bromide. The phylogenetic relationships among 37 accessions of the genus Camellia were assessed using the modified AFLP technique and cluster analysis. The accessions, 24 Japanese tea cultivars, seven Korean wild tea varieties and six Camellia species closely related to tea, were clustered into five groups; Japanese tea cultivars closely related to 'Yabukita', those not closely related to 'Yabukita', Chinese tea cultivars and Korean wild tea varieties, Assam type black tea cultivars, and Camellia species closely related to tea. The results of this study indicated that the morphological characteristics and the origins of the tea cultivars were well reflected in the clustering of the cultivars based on the AFLP analysis, and that the AFLP technique might find its use as an efficient and effective tool for determining phylogenetic relationships among tea cultivars.
\end{abstract}

\section{INTRODUCTION}

Most plants of the genus Camellia are indigenous to Southeast Asia. Sealy (1958) classified the genus into 82 species and Chang and Bartholomew (1984) reported 200 species of the genus. Number of species in the genus Camellia is generally thought to be 135 to 300 (Linda and Parks, 2000). In addition to morphological studies, various approaches have been tried to elucidate the relationships of the species in the genus, including chromosome analysis (Kondo, 1975; Uemoto et al., 1980), isozyme analysis (Wendel and Parks, 1983), pigment analysis (Sakata et al., 1981), RAPD analysis (Lee et al., 1995), and chloroplast DNA analysis (Lee and Nou, 1999; Prince and Parks, 2001).

Tea (Camellia sinensis) is commercially the most important and widely cultivated plant in the genus Camellia. Tea is divided into two large groups, Assam tea and China tea. Assam tea plants are not winter-hardy and have large leaves with high catechin concentration. China tea plants have small leaves with low catechin concentration and are

\footnotetext{
* Present address: Laboratory of Agricultural Ecology, Division of Agricultural Botany, Department of Plant Resources, Faculty of Agriculture, Kyushu University, Kasuya 811-2307, Japan

+ Corresponding author (E-mail: leesha@sunchon.sunchon.ac.kr)
} 
relatively resistant to cold weather. Assam tea leaves are used to make fermented black tea, whereas China tea leaves are used to make semi- and non-fermented teas (Kim, 1996). It is thought that the tea cultivars of today have both the genes of Assam tea and China tea origin due to introgressions during their breeding process.

RAPD (random amplified polymorphic DNA) has been used to elucidate genetic relationships among various organisms. It has, however, its own limit due to the lack of reproducibility. Recently, AFLP (amplified fragment length polymorphism) has been successfully used to analyze genetic relationships even in species where polymorphism is low (Kang et al., 1996; Mace et al., 1999; Prakash et al., 2002; Tsuji and Ohnishi, 2001). A genetic linkage map for Assam tea cultivars has been constructed using AFLP technique (Heckett et al., 2000). The present study has been conducted to evaluate the usefulness of AFLP in analyzing the relationships among $C$. sinensis and to determine the genetic relationships among Japanese tea cultivars and Korean wild tea varieties.

\section{MATERIALS AND METHODS}

\section{Plant material}

A total of 37 accessions of the genus Camellia was used in this study. The origins and sources of the accessions were listed in Table 1 . Twenty-four tea $(C$. sinensis $)$ cultivars were obtained from the Tea Branch, Miyazaki Prefectural Agricultural Experiment Station, Miyazaki, Japan and seven Korean wild tea varieties were from Posung Tea Experiment Station, Korea. Six Camellia species closely related to C. sinensis were obtained from the Institute of Vegetable and Tea Science, Kagoshima, Japan.

\section{DNA isolation and AFLP analysis}

DNA was extracted from $0.1 \mathrm{~g}$ fresh leaf samples of all accessions using the Nucleon PhytoPure DNA extraction kit (Amersham Life Science).

The AFLP protocol described by Vos et al. (1995) was employed with some modifications using the AFLP core reagent kit and the AFLP starter primer kit of GibcoBRL (Life Technologies, U.S.A.). For each sample, $125 \mathrm{ng}$ of genomic DNA was digested at $37^{\circ} \mathrm{C}$ for $2 \mathrm{~h}$ using restriction enzymes EcoRI and MseI. Restricted DNA fragments were ligated with EcoRI and $M s e I$ adapters using T4 DNA ligase. In pre-selective amplification, ligation mixture was amplified using primers complementary to the adapters with one additional selective 3' nucleotide. The pre-selective PCR amplification consisted of 20 cycles of denaturation at $90^{\circ} \mathrm{C}$ for $30 \mathrm{sec}$, annealing at $56^{\circ} \mathrm{C}$ for $60 \mathrm{sec}$ and extension at $72^{\circ} \mathrm{C}$ for $60 \mathrm{sec}$. Selective amplification of the pre-amplified products was carried out using 10 primer sets with three selective nucleotides for the EcoRI digested side and three selective nucleotides for the $M s e \mathrm{I}$ digested side. The selective amplification was carried out in a Perkin Elmer 9600 thermal cycler. The amplification was initiated by a cycle of denaturation at $94^{\circ} \mathrm{C}$ for $30 \mathrm{sec}$, annealing at $65^{\circ} \mathrm{C}$ for $30 \mathrm{sec}$ and extension at $72^{\circ} \mathrm{C}$ for $60 \mathrm{sec}$. The initial cycle was followed by the same cycle for 12 times with lowered annealing temperature $\left(0.7^{\circ} \mathrm{C}\right.$ per cycle, final temperature of $\left.56^{\circ} \mathrm{C}\right)$. This was followed by $23 \mathrm{cycles}$ of $95^{\circ} \mathrm{C}$ for $30 \mathrm{sec}, 56^{\circ} \mathrm{C}$ for $30 \mathrm{sec}$, and $72^{\circ} \mathrm{C}$ for $60 \mathrm{sec}$. Amplified DNA fragments were separated by polyacrylamide gel electrophoresis. The gel was made on a $16 \mathrm{~cm} \times 16 \mathrm{~cm}$ glass plate, and consisted of $13 \%$ running gel (in $0.378 \mathrm{M}$ Tris- $\mathrm{HCl}, \mathrm{pH}$ 
Table 1. Accessions used for AFLP analysis

\begin{tabular}{|c|c|c|c|}
\hline No. & Accessions & Species & Origin and source \\
\hline 1 & Yabukita & C. sinensis var. sinensis & Selection from seedlings, Shizuoka \\
\hline 2 & Okumidori & C. sinensis var. sinensis & Yabukita $\times$ NN29 \\
\hline 3 & Meiryoku & C. sinensis var. sinensis & Yabukita $\times Z-1$ \\
\hline 4 & Saemidori & C. sinensis var. sinensis & Yabukita $\times$ Asatuyu \\
\hline 5 & Kanayamidori & C. sinensis var. sinensis & S6 6 Yabukita \\
\hline 6 & Okuyutaka & C. sinensis var. sinensis & Yutakamidori $\times \mathrm{F}_{1} \mathrm{NN} 8($ Tamamidori $\times \mathrm{S} 6$ ) \\
\hline 7 & Fushun & C. sinensis var. sinensis & $\mathrm{Z}-1 \times$ Kanayamidori \\
\hline 8 & Yutakamidori & C. sinensis var. sinensis & Selection from seedlings of Asatuyu \\
\hline 9 & Sakimidori & C. sinensis var. sinensis & $\mathrm{NN} 27 \times \mathrm{ME} 52$ \\
\hline 10 & Unkai & C. sinensis var. sinensis & Takachiho $\mathrm{x} \mathrm{F}_{1}$ \\
\hline 11 & Yamanami & C. sinensis var. sinensis & Selection from Chinese seedlings \\
\hline 12 & Fukumidori & C. sinensis var. sinensis & Yabukita $\times \mathrm{F}_{1}($ Sayamamidori $\times$ Yabukita) \\
\hline 13 & Yaeho & C. sinensis var. sinensis & Selection from seedlings Yaeho, Shizuoka \\
\hline 14 & Takachio & C. sinensis var. sinensis & Selection from seedlings, Miyazaki \\
\hline 15 & Makinoharawase & C. sinensis var. sinensis & Selection from seedlings, Shizuoka \\
\hline 16 & Sayamamidori & C. sinensis var. sinensis & Selection from seedlings, Uji \\
\hline 17 & Asatuyu & C. sinensis var. sinensis & Selection from seedlings, Uji \\
\hline 18 & Benihomare & C. sinensis var. assamica & Black tea, Selection from India seedlings \\
\hline 19 & Hatumomiji & C. sinensis var. assamica & Black tea, $\mathrm{Ai} 2 \times \mathrm{NKa} 05$ \\
\hline 20 & Benitachiwase & C. sinensis var. assamica & Black tea, $\mathrm{Ai} 2 \times \mathrm{NKa01}$ \\
\hline 21 & Sunmei & C. sinensis var. sinensis & Yutakamidori $\times$ NN8 \\
\hline 22 & Uron-1 & C. sinensis var. sinensis & Uron Chinese var. from Taiwan \\
\hline 23 & Uron-2 & C. sinensis var. sinensis & Uron Chinese var. from China \\
\hline 24 & Sri Lanka & C. sinensis var. assamica & Black tea var. from Sri Lanka \\
\hline 25 & $\mathrm{~K}-1$ & C. sinensis var. sinensis & Collection from Hyangrimsa, Korea \\
\hline 26 & $\mathrm{~K}-2$ & C. sinensis var. sinensis & Collection from Seonamsa, Korea \\
\hline 27 & $\mathrm{~K}-3$ & C. sinensis var. sinensis & Collection from Daeheungsa, Korea \\
\hline 28 & $\mathrm{~K}-4$ & C. sinensis var. sinensis & Collection from Hwaumsa, Korea \\
\hline 29 & $\mathrm{~K}-5$ & C. sinensis var. sinensis & Collection from Sanggyesa, Korea \\
\hline 30 & $\mathrm{~K}-6$ & C. sinensis var. sinensis & Collection from Boriam, Korea \\
\hline 31 & $\mathrm{~K}-7$ & C. sinensis var. sinensis & Collection from Keumsansa, Korea \\
\hline 32 & Rosaeflora & C. rosaeflora & Collection by IVT, Kagoshima, Japan \\
\hline 33 & Oleifera & C. oleifera & Collection by IVT, Kagoshima, Japan \\
\hline 34 & Miyagii & C. miyagii & Collection by IVT, Kagoshima, Japan \\
\hline 35 & Japonica & C. japonica & Collection by IVT, Kagoshima, Japan \\
\hline 36 & Sasanqua & C. sasanqua & Collection by IVT, Kagoshima, Japan \\
\hline 37 & Hybrid-1 & C. sinensis $\times$ C. japonica & Crossing line by IVT, Kagoshima, Japan \\
\hline
\end{tabular}

1-24: from Tea Branch, Miyazaki Prefectural Agricultural Experiment Station, Miyazaki, Japan. 25-31: from Posung Tea Experiment Station, Korea.

32-37: from Institute of Vegetable and Tea Science, Kagoshima, Japan.

$8.8,11 \mathrm{~cm}$ in length) and 5\% stacking gel (in $0.133 \mathrm{M}$ Tris- $\mathrm{HCl}, \mathrm{pH} 6.8,1.5 \mathrm{~cm}$ in length). Electrophoresis was performed for $3 \mathrm{~h}$ at $150 \mathrm{~W}$ constant power with Tris-Glycine buffer (25 mM Tris and $192 \mathrm{mM}$ Glycine, $\mathrm{pH}$ 8.3). Gels were stained with ethidium bromide for $10 \mathrm{~min}$, and photographed under UV.

\section{Data analysis}

For each accession, a binary matrix reflecting specific AFLP-band presence (1) or 
absence (0) was generated. Only clear bands were scored from the gel photograph magnified using Photoshop program (version 6.0). Cluster analysis and dendrogram generation was performed by the unweighted pair group method using arithmetic mean (UPGMA) clustering method with the NTSYS package (Tateno et al., 1982).

\section{RESULTS AND DISCUSSION}

\section{Modification of AFLP analysis methodology}

Several modifications of the methodology were made in this study to simplify the analysis. The modifications did not cause any significant change in the results (Figs. 1-3). First, the amount of the reagents for restriction digestion, ligation of adapters, preamplification and selective AFLP amplification were reduced to half of the amount recom-

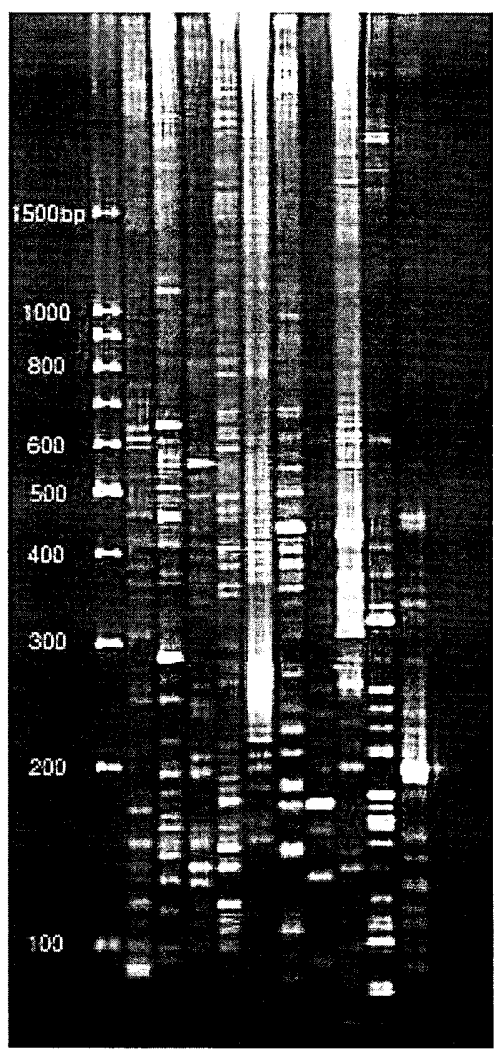

Fig. 1. AFLP patterns of tea (Yabukita) detected with ten primer combinations. Primer combinations were from left to right: $\mathrm{E}+\mathrm{AAC} / \mathrm{M}+\mathrm{CTT}, \mathrm{E}+$ $\mathrm{AAG} / \mathrm{M}+\mathrm{CAG}, \mathrm{E}+\mathrm{ACT} / \mathrm{M}+\mathrm{CAG}, \mathrm{E}+\mathrm{AGC} / \mathrm{M}+\mathrm{CTG}, \mathrm{E}+\mathrm{ACA} / \mathrm{M}+\mathrm{CAC}$, $\mathrm{E}+\mathrm{AGG} / \mathrm{M}+\mathrm{CAC}, \mathrm{E}+\mathrm{AGG} / \mathrm{M}+\mathrm{CTT}, \mathrm{E}+\mathrm{AGC} / \mathrm{M}+\mathrm{CTT}, \mathrm{E}+\mathrm{ACG} / \mathrm{M}+$ $\mathrm{CTA}, \mathrm{E}+\mathrm{ACT} / \mathrm{M}+\mathrm{CAT}$ ( $\mathrm{E}$ and $\mathrm{M}$ indicate $E c o \mathrm{RI}$ and $M s e \mathrm{I}$, respectively). The numbers on the left side indicate the sizes of the DNA fragments in base pairs. 


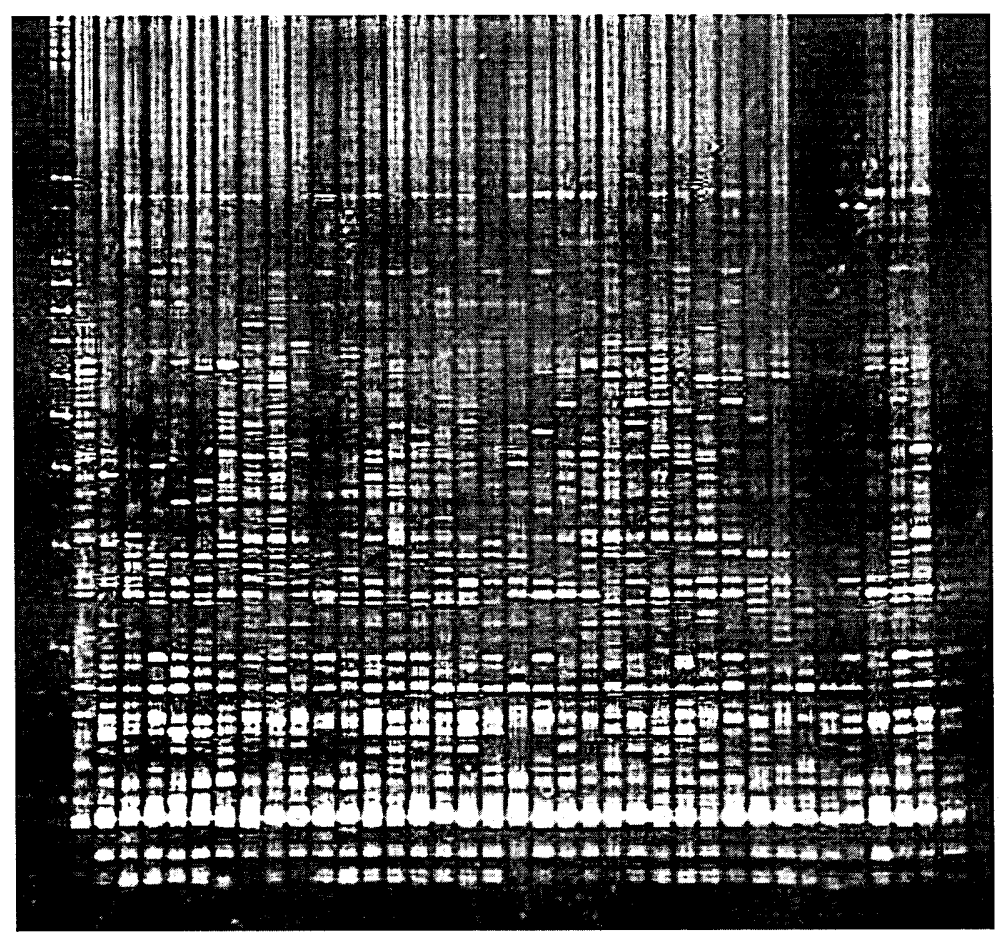

Fig. 2. AFLP patterns of the 37 accessions detected with the $E+A A C / M+C T T$ primer combination. The accessions were 1 to 37 (from left to right) as appeared in Table 1. The left-most lane was DNA size markers.

mended by the supplier (GibcoBRL, Life Technologies, U.S.A.). For example, $125 \mathrm{ng}$ DNA, and 1.25 U each of EcoRI and MseI were used for restriction digestion (250 ng DNA, and $2.5 \mathrm{U}$ each of $E c o \mathrm{RI}$ and $M s e \mathrm{I}$ were recommended by the supplier). Second, the procedure could be simplified by using unlabeled primer and by staining the gel with ethidium bromide. The supplier recommends labeling the primer with $\mathrm{P}^{32}$ prior to selective amplification and autoradiographing the gel. Alternatively, some researchers silver-stained the gel without labeling the primer. Third, the gel length was reduced to $11 \mathrm{~cm}$ (made on a $16 \mathrm{~cm} \times 16 \mathrm{~cm}$ glass plate) and the gel concentration was increased to $13 \%$ polyacrylamide. By this, the electrophoresis could be completed in a shorter time and the gel could be handled more easily and safely. The difficulty in scoring due to the shortened distances between the bands could be circumvented by magnifying the image of the photographed gel using a image processing program. In this study, Photoshop version 6.0 was used for the purpose.

\section{AFLP pattern and extent of polymorphism}

Sixty-four AFLP primer combinations were tested for their applicability in tea analy- 


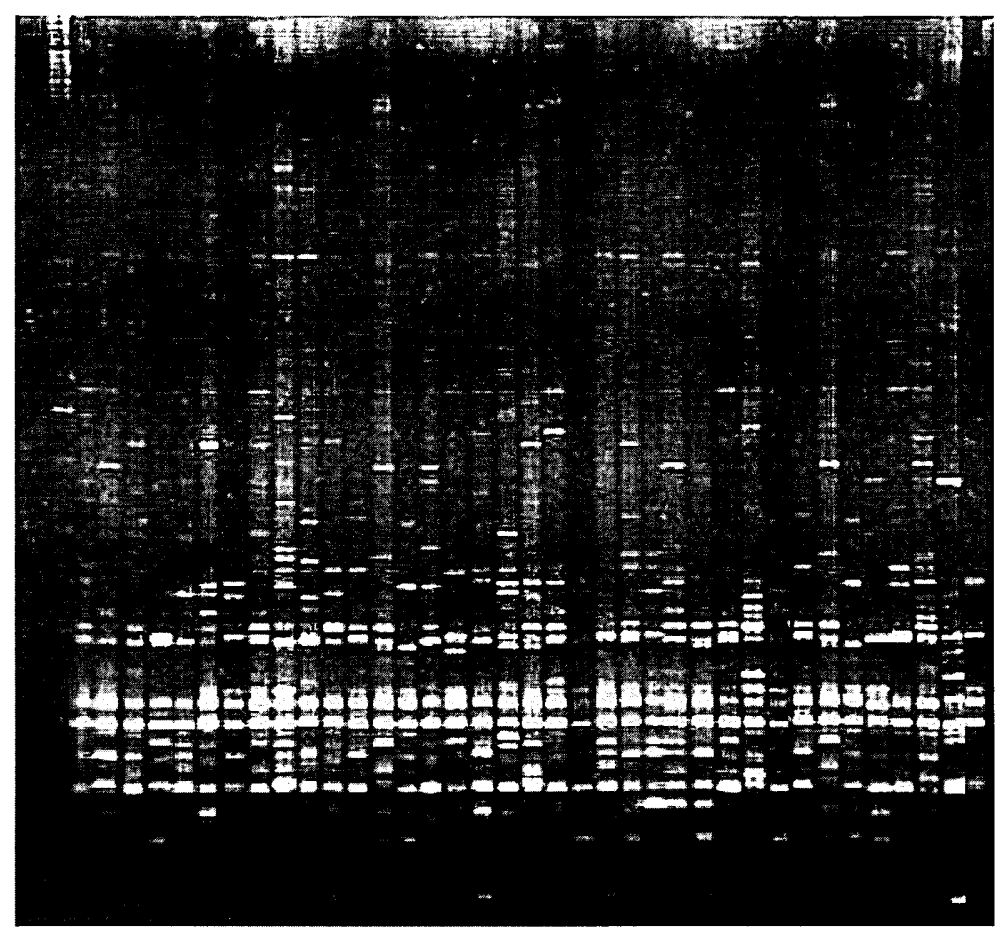

Fig. 3. AFLP patterns of the 37 accessions detected with the $E+A C T / M+C A G$ primer combination. The accessions were 1 to 37 (from left to right) as appeared in Table 1. The left-most lane was DNA size markers.

sis using 'Yabukita' as a test material, and 10 primer combinations were selected for further study based on the number and clarity of the bands appeared on the gel (Table 2).

With the 10 primer combinations and the 37 accessions, a total of 386 bands were detected on the gel, and the number of bands per primer combination ranged from 28 with $\mathrm{E}+\mathrm{ACT} / \mathrm{M}+\mathrm{CAG}$ to 49 with $\mathrm{E}+\mathrm{AAC} / \mathrm{M}+\mathrm{CTT}$ with an average of 38.6 bands per primer combination (Table 3). Most of the amplified fragments were 50-600 base pairs in size (Figs. 1-3). Of the 386 bands, 209 (54.1\%) were found to be polymorphic, and the number of polymorphic bands per primer combination ranged from 14 with $\mathrm{E}+\mathrm{AGC} / \mathrm{M}+$ CTT to 34 with $\mathrm{E}+\mathrm{AAG} / \mathrm{M}+\mathrm{CAG}$ with an average of 20.9 bands per primer combination. Compared to the result of RAPD analysis of tea accessions (Lee et al., 1996), the AFLP analysis resulted in more bands per primer and a higher percentage of polymorphic bands. In the RAPD analysis, an average of 10.6 bands per primer set was detected and the ratio of polymorphic bands was $18.9 \%$. These results suggested that AFLP might be a useful tool for the identification and classification of Camellia species and tea cultivars. The ratio of polymorphic AFLP bands obtained with the tea accessions was found to be higher than those obtained with other plants. The ratios of polymorphic bands were $36 \%$ 
Table 2. Applicability of primer combinations for AFLP analysis of tea cultivars

\begin{tabular}{lcccccccc}
\hline \multirow{2}{*}{ EcoRI primer } & \multicolumn{7}{l}{ MseI primer } \\
& M+CAA & M+CAC & M+CAG & M+CAT & M+CTA & M+CTC & M+CTG & M+CTT \\
\hline E+AAC & - & + & + & + & + & + & - & + \\
E+AAG & + & + & + & + & + & + & - & - \\
E+ACA & + & - & + & + & - & + & - & + \\
E+ACC & - & - & + & - & + & + & - & + \\
E+ACG & + & + & + & + & - & + & - & + \\
E+ACT & + & + & + & + & + & - & - & + \\
E+AGC & - & + & + & - & + & + & - & + \\
E+AGG & - & - & + & + & - & + & - & + \\
\hline
\end{tabular}

${ }^{1}$ Applicability was tested using Yabukita as a test material, and judged based on the number and clarity of bands. -, bad; + , good; $H$, excellent.

${ }^{2} \mathrm{E}+3$ and $\mathrm{M}+3.3$ ' end-selective nucleotides of the primers complementary to the EcoRI- and MseI-adapter, respectively.

Table 3. Primer combinations used and the numbers of detected and polymorphic bands

\begin{tabular}{ccccc}
\hline EcoRI +3 & MseI+3 & $\begin{array}{l}\text { Number of } \\
\text { detected bands }\end{array}$ & $\begin{array}{l}\text { Number of } \\
\text { polymorphic bands }\end{array}$ & $\begin{array}{c}\text { Percentage of } \\
\text { polymorphism }\end{array}$ \\
\hline AAC & CTT & 49 & 31 & 63.3 \\
AAG & CAG & 46 & 34 & 73.9 \\
ACT & CAG & 28 & 16 & 57.1 \\
AGC & CTG & 35 & 17 & 48.6 \\
ACA & CAC & 39 & 16 & 41.0 \\
AGG & CAC & 44 & 20 & 45.5 \\
AGG & CTT & 37 & 19 & 51.4 \\
AGC & CTT & 29 & 14 & 48.3 \\
ACG & CTA & 42 & 22 & 52.4 \\
ACT & CAT & 37 & 20 & 54.1 \\
\hline Total & & 386 & 209 & 54.1 \\
\hline
\end{tabular}

with soybean (Maughan et al., 1996) and 33.2\% with rice (Subudhi et al., 1998).

\section{Cluster analysis}

Cluster analysis was performed with similarity coefficient matrices calculated from AFLP markers to generate a dendrogram. The similarity coefficients ranged from 0.55 to 1.0. In the dendrogram, the 37 accessions which consisted of 31 tea cultivars $(C$. sinensis) and six Camellia species closely related to $C$. sinensis were clustered into five large groups (Fig. 4). The first group was mainly composed of 'Yabukita' and the cultivars derived from 'Yabukita', the second group Japanese tea cultivars not related to 'Yabukita', the third Chinese cultivars and Korean wild tea varieties, the fourth Assam type black tea cultivars, and the fifth group was composed of six Camellia species closely related to $C$. sinensis.

Either paternal or maternal parent of the accessions of the first group was 'Yabukita', with exceptions of 'Makinoharawase' and the Korean tea variety collected from Seonamsa, 


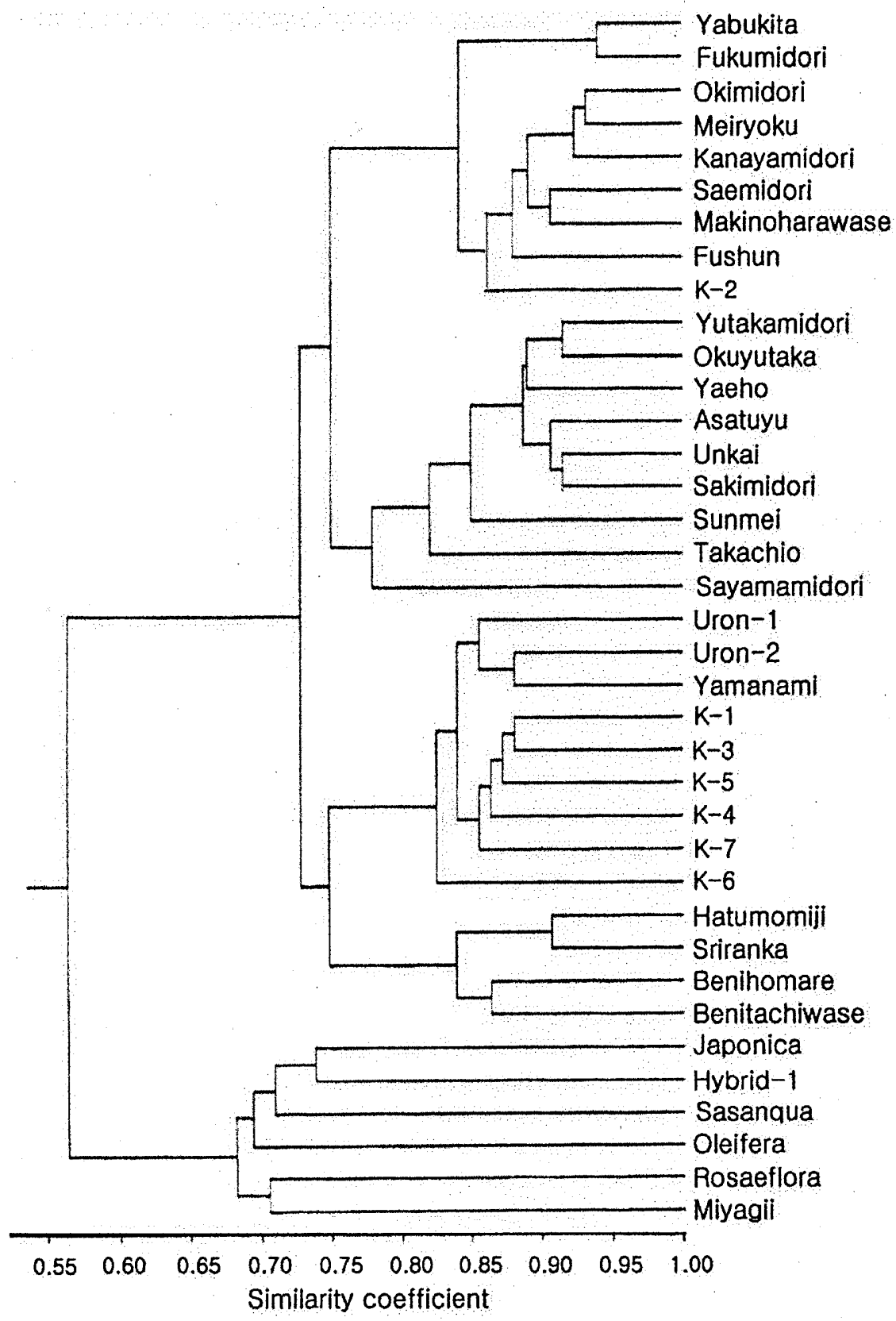

Fig. 4. Dendrogram of the 37 accessions constructed from the AFLP data. The accessions are listed in Table 1. 
Korea. The paternal parent of 'Fushun' (Z-1 $\times$ 'Kanayamidori'), 'Kanayamidori' (S-6 $\times$ 'Yabukita') is an offspring of 'Yabukita' (Yamaguchi et al., 1992). Among the accessions of the first group, 'Yabukita' and 'Fukumidori' showed highest similarity with an index of 0.94 , reflecting the fact that 'Fukumidori' is a progeny of 'Yabukita' $\times F_{1}$ ('Sayamamidori' $X$ 'Yabukita'). The presence of the Korean tea variety collected from Seonamsa (K-2) in the first group indicated that introgressions might have occurred between Korean wild tea varieties and 'Yabukita' when Japanese tea cultivars were introduced to Korea. Some Japanese tea cultivars and some Korean wild tea varieties also belonged to the same group in the RAPD analysis (Lee et al., 1996). 'Makinoharawase' was selected from the seedlings obtained in Shizuoka, where 'Yabukita' originated from. The result of this study indicated that 'Makinoharawase' might also be produced by introgression with 'Yabukita'.

The second group was composed of nine accessions not related to 'Yabukita'. The accessions in this group were either naturally selected from seedlings or artificially bred. Among the accessions of the second group, 'Yutakamidori' and 'Okuyutaka', and 'Unkai' and 'Sakimidori' showed highest similarity with an index of 0.91. 'Okuyutaka' is an offspring of 'Yutakamidori'. 'Sayamamidori' showed lowest similarity to other accessions of the group. 'Sayamamidori' is a naturally selected cultivar and its origin is not clearly known. It was suggested that 'Sayamamidori' might have gone through less introgression with other tea varieties.

The third group was composed of nine accessions of Chinese tea cultivars and Korean wild tea varieties. A Chinese tea cultivar, 'Uron-2', was found to be more closely related to 'Yamanami' than another Chinese cultivar, 'Uron-1'. 'Yamanami' was bred from a Chinese seedling. The presence of several Korean wild tea varieties and Chinese tea cultivars in the same group might indicate that many Korean tea varieties have been introduced from China. The low similarity among the accessions of this group might reflect the fact that the accessions were not artificially bred varieties but naturally collected varieties from wild.

The fourth group is composed of four accessions of Assam type black tea varieties. 'Hatumomiji' was closely related to the variety collected from Sri Lanka, and 'Benihomare' to 'Benitachiwase'. The fifth group showed low similarity to other groups and is composed of six accessions of Camellia species closely related to $C$. sinensis. Japonica was closely related to Hybrid-1, a hybrid of Camellia japonica and C. sinensis. Japonica and Hybrid-1 were related to Sasanqua (Camellia sasanqua).

The results of this study indicated that the morphological characteristics and the origins of the tea cultivars were well reflected in the clustering of the cultivars based on the AFLP analysis, and that the AFLP technique might find its use as an efficient and effective tool for determining genetic relationships among tea cultivars.

\section{ACKNOWLEDGMENTS}

This work was supported by the grants from Sunchon National University and Agricultural R\&D Promotion Center. The authors thank the Tea Branch, Miyazaki Prefectural Agricultural Experiment Station, Miyazaki, Japan, the Institute of Vegetable and Tea Science, Kagoshima, Japan, and Posung Tea Experiment Station, Korea for providing tea samples. 


\section{REFERENCES}

Chang, H. T. and B. Bartholomew 1984 Camellias. Timber Press. Portland, Oregon

Heckett, C. A., F. N. Wachira, S. Paul, W. Powell and R. Waugh 2000 Construction of a genetic linkage map for Camellia sinensis (tea). Heredity, 85: 346-355

Kang, B. C., J. W. Yu, M. H. Lee and B. D. Kim 1997 Applicability of AFLP in hot pepper genetic analysis. J. Kor. Soc. Hort. Sci., 38: 698-703

Kim, J. T. 1996 The science and culture of tea. Borimsa pp101-153 (in Korean)

Kondo, K. 1975 Cytological studies in cultivated species of Camellia. PhD thesis, University of North Carolina, Chapel Hill.

Lee, S. H., H. S. Choi, R. H. Kim, H. Y. Lee and I. S. Nou 1995 Identification of Korean wild tea plants and Japanese green tea cultivar using RAPD markers. J. Kor. Tea Soc., 1:129-148

Lee, S. H. and I. S. Nou 1999 Characteristics of chloroplast DNA restriction fragments in Camellia sinensis. J. Kor. Tea Soc., 5: 33-44 (in Korean)

Lee, S. H., C. H. Kim, W. S. Song and I. S. Nou 1996 Phylogenetic relationship and genetic variation among varieties of Hibiscus syriacus based on RAPD analysis. Korean J. Breed., 28: 445-456 (in Korean)

Linda, M. P. and C. R. Parks 2000 Estimation of relationships of Theoideae (Theaceae) inferred from DNA data. Intl. Camellia J., 32: 79-84

Mace, E. S., R. N. Lester and C. G. Gebhardt 1999 AFLP analysis of genetic relationships among the cultivated eggplant. Solanum melongena L., and wild relatives (Solanaceae). Theor. Appl. Genet., 99: $626-633$

Prakash, N. S., M. C. Combes, N. Somanna and P. Lashermes 2002 AFLP analysis of introgression in coffee cultivars (Coffea arabica L.) derived from a natural interspecific hybrid. Euphytica, 124: $265-271$

Prince, L. M. and C. R. Parks 2001 Phylogenetic relationships of Theaceae inferred from chloroplast DNA sequence data. Amer. J. Bot., 88: 309-320

Rogers, J. S. 1972 Measures of genetic similarity and genetic distance. Studies in genetics VII. Univ. Texas Publ., 7213: 145-153

Rolf, F. J. 1993 NTSYS-pc: numeral taxonomy and multivariate analysis system. Version 1.80. Exeter Software, New York

Sakata, Y., S. Nagayoshi and K. Arisumi 1981 Studies on the flower colours in the Camellia II. On the anthocyanin comstitution in the cultivars of $C$. japonica, C. japonica subsp. rusticana, $C$. sasanqua, C. hiemalis, C. vernalis and C. wabisuke. Mem. Fac. Agr. Kagoshima Univ., 17: 79-94 (in Japanese)

Sealy, J. R. 1958 A revision of the genus Camellia. Royal Hort. Soc. London. 239pp

Subudhi, P. K., S. Nandi, C. Casal, S. S. Virmandi and N. Huang 1998 Classification rice germplasm: III. High resolution fingerprinting of cytoplasmic genetic male sterile (CMS) lines with AFLP. Theor. Appl. Genet., 96: 941-949

Tateno, Y., M. Nei and F. Tajama 1982 Accuracy of estimated phylogenetic trees from molecular data. Distantly related species. J. Mol. Evol., 18: 387-404

Tsou, C. U. 1998 Early floral development of Camellioideae (Theaceae). Amer. J. Bot., 85: 1531-1547

Tsuji, K. and O. Ohnishi 2001 Phylogenetic relationships among wild and cultivated tartary buckwheat (Fagopyrum tataricum Gaert.) populations revealed by AFLP analyses. Genes Genet. Syst., 76: 47-52

Uemoto, S., T. Tanaka and K. Fujieda 1980 Cytogenetic studies on the origin of Camellia vernalis I. On the meiotic chromosomes in some related Camellia forms in Hirado Island. J. Japan. Soc. Hort. Sci., 48: 475-482

Vos, P., R. Horgers, M. Bleeker, M. Reijans, T. van de Lee, M..Hornes, A. Frijters, J. Pot, J. Peleman, M. Kuiper and M. Zabeau 1995 AFLP: a new technique for DNA fingerprinting. Nucl. Acids Res., 23: $4407-4414$

Wachira, F. N., R. Waugh, C. A, Hechett and W. Powell 1995 Detection of genetic diversity in tea (Camellia sinensis) using RAPD markers. Genome, 38: 201-210

Welsh, J. and M. McClelland 1990 Fingerprinting genomes using PCR with arbitrary primers. Nucl. Acids Res., 18: 7213-7218 
Wendel, J. F. and C. R. Parks 1983. Cultivar identification in Camellia japonica L. using allozyme polymorphisms. J. Amer. Soc. Hort. Sci., 108: 290-295

Yamaguchi, S., T. Takyu, N. Ikeda, Y. Takeda, A. Watanabe, Y. Yanase and S. Amma 1992 A new cultivar, 'Fushu', for green tea. Bull. Natl. Res. Inst. Veg. and Tea, B5: 1-13 (in Japanese) 